Назаревич Л. Т. кандидат філологічних наук, доцент

Тернопільський національний технічний університет імені Івана Пулюя

\title{
ТРАНСФОРМАЦІЯ МОВНО-СТИЛІСТИЧНИХ ЗАСОБІВ ТВОРЕННЯ ХУДОЖНІХ ОБРАЗІВ У МИСТЕЦЬКІЙ СПАДЩИНІ ЯКОВА СТРУХМАНЧУКА
}

У статті окреслено художній світ талановитого графіка, живописия, карикатуриста, портретиста, мистецтвознавия Якова Струхманчука. Методологічною базою послугували праці І. Франка, Ю. Лотмана, Ф. Погребенника та ін. На основі шаржів на М. Грушевського, М. Козоріса, Д. Рудика, Д. Загула, М. Кічуру та ін., які супроводжувалися текстовим коментарем В. Шворки, проаналізовано невербальні твори, зосереджено увагу на художній деталі, щзо несе неабияке смислове та емочійне навантаження.

Ключові слова: Я. Струхманчук, В. Шворка, інтермедіальність, карикатура, шарж, живопис, паратекст.

В статье очерчено художественный мир талантливого графика, художника, карикатуриста, портретиста, искусствоведа Якова Струхманчука. Методологической базой послужили научные труды И. Франко, Ю. Лотмана, Ф. Погребенника и др. Полагаясь на шаржи, изображающие М. Грушевского, М. Козориса, Д. Рудыка, Д. Загула, М. Кичуру и др., которые сопровождались текстовым комментарием В. Шворки, проанализированы невербальные произведения, сосредоточено внимание на художественной детале, которая несет огромную смысловую и эмоциональную нагрузку.

Ключевые слова: Я. Струхманчук, В. Шворка, интермедиальность, карикатура, шарж, живопись, паратекст.

The article deals with the artistic world of talented graphist, artist, caricaturist, portraitist, fine art expert Yakiv Strukhmanchuk. Works of I. Franko, Yu. Lotman, F. Pogrebennyk and others make the methodological basis of the investigation. Based on the caricatures on M. Grushevskyi, M. Kozoris, D. Rudyk, D. Zagul, M. Kichura and others that were accompanied by the text comments of V.Shvorka, non-verbal works have been analized with much attention being concentrated on the artistic detail that carries out considerable emotional and meaning yield.

Key words: Ya. Strukhmanchuk, V. Shvorka, intermediality, caricature, fine arts, paratext. 
Духовні виміри внутрішнього світу людини упродовж багатьох віків викликали неабиякий інтерес у письменників, філософів, художників, науковців. Жанри літератури, живопису, графіки, архітектури, музики, кіно на початку XX століття доступними їм засобами відтворювали індивідуальну картину світу творчої особистості. Внаслідок цього на зламі віків поглибився взаємозв'язок між різними видами мистецтва. Вважаємо за доцільне на матеріалі творчості Якова Струхманчука простежити взаємодію літератури та малярства.

3 юнацьких років Яків ілюстрував галицькі рукописні журнали («Поступ», «Бджола», «Муха», «Мітла», «Оса»), гумористично-сатиричні часописи («Комар», «Зеркало», «Жало»), де зарекомендував себе першокласним карикатуристом. Митець зумів лише кількома штрихами передати індивідуальне сприйняття портретованих та їхній внутрішній світ.

Грунтовна професійна освіта у Краківській Академії красних мистецтв (1905-1910) та Паризькій Академії мистецтв (1910-1912), туга за Батьківщиною та близькими надихнули митця до написання меланхолійно-тужливих портретів, виконаних вибагливою технікою пастелі («Рожі», «Портрет», «Бретонець», «Зимовий пейзаж», «Портрет художника Івана Северина», «Портрет жінки в капелюсі»). Окрім цього автор створив низку дружніх шаржів, ілюстрацій до другого видання «Історії України» Миколи Аркаса («Павлюк розсилає універсали», «Дорошенко приймає турецьких послів», «Облога Буші», де зображено жінку сотника Зависного, що висаджує в повітря замок, аби він не дістався полякам); твору Осипа Маковея «Ревун», де висміяно фарисейство та обман «ревунів», які приходять до влади; книжки Михайла Козоріса «Дві сили» та низки статей і карикатур у краківських та українських журналах і газетах. Яків Струхманчук неодноразово звертався до образу Шевченка, ілюстрував твори І. Франка («Воa constriktor», «Каменярі», «В поті чола»), І. Карпенка-Карого («Сто тисяч»), Н. Кобринської («Дух часу»), П. Куліша («Чорна рада») та ін. За- 
уважимо, що подібні ілюстрації, творячи паратекст відомих шедеврів, допомагали читачам уявляти персонажів саме такими, якими їх зображували. Особлива інтерпретація відкривала таке семантичне поле асоціацій, про яке й не здогадувався сам автор.

Жанр карикатури обирає незначна кількість митців із тонким почуттям гумору, із загостреним сприйняттям світу та вмінням схопити настрій оточуючих, відчути найменші зміни в їхніх поглядах. Карикатура дозволяє викрити або висміяти вади конкретної людини чи явища, акцентуючи на найгірших рисах індивідуума. Тому із позицій міжмистецької взаємодії цікаво проаналізувати низку шаржів (як різновиду карикатури) на М. Грушевського, М. Козоріса, Д. Рудика, М. Кічуру. Яків Струхманчук надавав перевагу м'якому, доброзичливому гомору, а не викривальній сатирі, тому саме у шаржах-портретах проявив себе неперевершеним майстром. Портрет, за Ю. Лотманом, «виокремлює ті риси людської особистості, яким приписується смислова домінанта», «портрет неначе спеціально, за самою природою жанру пристосований для того, аби втілити саму сутність людини» [Лотман 2002: 352, 363]. Юрій Лотман невипадково писав, що існує два важливі питання: по-перше, хто намальований, а по-друге, хто малював, що породжує ще два важливих питання: яка думка зображеної людини закарбована на ії обличчі та яку думку художник виразив своїм зображенням [Лотман 2002: 363].

Художникові мистецтво допомагало зберегти власну ідентичність, а його колегам побачити себе очима «іншого». Так, цікавими є два шаржі на Михайла Грушевського, виконані у різний час. На першому зображено огрядного бородатого Грушевського, що тримає в правій руці закриту товсту і велику книгу, де на палітурці друкованими буквами написано «Історія України-Руси». Тут погляд автора впевнений і спрямований вперед. Коли реципієнт дивиться на перо за вухом та ліву руку, що вказує на книжку, то у нього виникає асоціація: історію написано - хто захоче, той зможе почерпнути для себе багато нового. У другому, на думку Олега 
Сидора, більш грунтовному шаржі, автор «Історії України-Руси» постає в образі Господа. Кулеподібне тіло, доброзичливе й мудре обличчя нагадує святого. Бачимо німб із викарбуваними датами «1885-1910» над чолом (художник його змалював світлим, високим, розумним). На цьому шаржі книга вже розкрита, художник прагне показати Грушевського в динаміці, у процесі роботи, адже у нього в руці перо, яким світоч науки вивів фразу: «Спочатку було слово». Саме це зображення доповнює зміст попереднього, змушує глядача замислитися над словом як першопричиною усього сущого, адже слово - це інформація про минуле, погляд на сучасне та майбутнє, втілення думок усього людства, зрештою, це переживання окремої особистості та усвідомлення себе частинкою всесвіту в соціокультурному просторі...

Зауважимо, вченого Струхманчук поважав і цінував, тому й, дивлячись на шаржі, глядач відчув ставлення художника до людини, зображеної на полотні. Серйозне, проте дуже добре, з м'якими рисами обличчя, довга борода, окуляри, перо і найважливіша деталь - величезна, товстелезна книга «Історія України-Руси» - свідчать про те, що Яків Струхманчук сприймав Михайла Грушевського як інтелектуала. Фоліант змальований так масштабно для того, аби підкреслити значущість цього видання для української культури й акцентувати на вкладену в неї важку розумову працю науковця. Через кілька років художник знову звернувся до образу вченого, надавши шаржу характеру станкового твору. Митець дуже тонко, виразно передав образ історика, приділивши багато уваги нюансам: виразу обличчя, погляду, рухам, міміці. «Не прагнучи до абсолютної портретної достовірності (а в шаржі це зовсім не потрібно), художник все ж зумів бездоганно відтворити не лише зовнішню подібність, але й притаманну М. Грушевському внутрішню творчу енергію» [Сидор 1997: 89].

Інтерпретація дружніх шаржів Якова Струхманчука, що супроводжуються текстами Віллі Шворки є свідченням того, що словесному наслідуванню передував малярський прототип: ілюст- 
рація переходить не із слова в малюнок, а навпаки - із малюнка в слово, що вимагає кодування та перекодування цих двох різних видів мистецтва всередині різних семіотичних систем та породжує низку труднощів. Детально про сприйняття поезії та малюнка йдеться у статті Івана Франка «Із секретів поетичної творчості». Перша проблема полягає у тому, що не завжди людині, що дивиться на малюнок, просто зрозуміти глибинну ідею, яку заклав у неї автор; інша проблема - у тому, що текст-пояснення обмежує уяву того, хто споглядає, інколи звужує рамки сприйняття. Підтвердженням такої думки є слова I. Франка: «... коли малярство апелює тільки до зору і тільки посередньо, при помочі зорових вражень, розбуджує в нашій душі образи, які найзвичайніше являються в асоиіації з даним зоровим враженням [...], то поезія апелює рівночасно до зору $і$ до слуху, а далі, при помочі слів, $і$ до всіх інших змислів $і$ може викликати такі образи в нашій душі, яких малярство ніяким чином викликати не може» [Франко 1981: 104]. У цьому випадку унікальність малюнків-шаржів якраз у тому, що вони становлять органічну цілісність із поетичним текстом Віллі Шворки, перед котрим постало непросте завдання - знайти відповідні засоби вираження для поезії, які би викликали у людини саме ті думки, до яких апелював художник. Візьмемо для прикладу шарж «ЗУП» - двоє чоловіків, сидячи на книжках, варять чиїсь голови. Один із них (Д. Загул), відкривши кришку, випускає джина і помішує те, що в посудині, інший (В. Атаманюк) із величезної ложки куштує їжу. Без перекодування складно пояснити задум художника. Поезія «ЗУП. Літорганізація «ЗУ» письменників» відразу ж розставляє всі крапки над «і»: «Щоб змічнити підкарпатські соки / Ми ЗУ-юшку варимо три роки, / Раптом у Варшаві рейвах, крик: / «Slovo Polske» попекло язик!» Автор до останнього рядка дає поясненя: «Slovo Polske» вмістило статтю, де вказує на нашу літорганізацію, як на небезпечну для державних підвалин Польщі». Малюнки настільки зливаються 3 текстом, що у свідомості назавжди закарбовується саме такий образ, який виник у реципієнта від першого сприйняття. 
Сповненою гумору є чорно-білий, штриховий, односюжетний шарж на Михайла Козоріса. Впадає у вічі величезний орлиний ніс письменника, що $є$ ознакою проникливості. Похнюплений i гордовитий поет із книжкою під пахвою намагається зрушити 3 місця, орючи цілину (тобто працюючи на творчій ниві). 3 малюнка видно, що така робота є важкою для п. Михайла. Карикатурист, відчувши хвилевий творчий застій колеги, прозоро натякнув йому, що будь-яка зупинка призводить до деградації. Чудовим поясненням до тексту є рядки Шворки: «Ой тягну, тягну, тягну плуг, / а з місия ані кроку: / За це хоч премію потяг - / нівроку!». Жанр шаржу має свою специфіку і в літературі - це чотиривірш, сповнений м'якого жарту з елементами іронії. На цьому прикладі бачимо, як завдяки вмінню цілісно сприймати та розуміти задум художника, поет може пролити світло на текст, а це, відтак, дозволяє збагнути взаємодію та взаємодоповнюваність двох різних видів мистецтва iз кардинально відмінними засобами вираження.

Заслуговує уваги й карикатура «Про себе» із зображенням Мелетія Кічури в глибокій задумі. На перший погляд, до цього малюнка не потрібно текстового коментаря, оскільки мова тіла говорить сама за себе: закладена рука за спину свідчить про самоконтроль персонажа, затиснута між незігнутими пальцями сигарета $\epsilon$ ознакою того, що людина намагається заспокоїтися або щось зрозуміти чи пояснити. Проте поезія: «На старті» я - / життя пливе / «Без керми» - Аж жаль бере, / що приз беруть / оферми» додає розуміння до шаржу. Федір Погребенник у статті «На переломі» зазначив: «...відзначають преміями-призами бездарних поетів, ... літературне життя пливе «без керми», не спрямовується в належне річище. Я. Струхманчук зобразив поета саме в хвилини роздумів над парадоксами життя» [Погребенник 1997: 73]. Повертаючись до аналізу поезії, бачимо, що Шворка використав назви двох збірок М. Кічури: «На старті» (1928) та «Без керми» (1910) у зворотньому порядку, «щьоб наголосити творчу еволюцію поета від позначених меланхолією, декадантськими настроями збірки 
«Без керма» до утвердження суспільної функиії громадянського покликання мистецтвва [Погребенник 1997: 73]. Перша збірка (34 вірші) вийшла за сприяння Богдана Лепкого, який побачив обдарування початківця. Збірка «На старті» - це роздуми про події Першої світової війни, біль, вилитий у творчість. Вірші Кічури ліричні, м'які, легкі, природні, сповнені фольклорних елементів. Струхманчук, відчувши душу митця, зумів уловити іiі філософські настрої, які йому вдалося вималювати на папері.

Дещо химерно-розхристаним, у творчому пошуку, стані внутрішньої тривоги зображено Дмитра Рудика. Обличчя напівоберта, погляд, спрямований назад, випукле чоло, піднятий угору ніс, розкуйовджена чуприна, перо за вухом, широкий крок вперед свідчить про вагання та неспокій персонажа. Промовистою є художня деталь - непропорційно великий портфель, який дуже міцно тримає Рудик. Асоціативне мислення підказує - всередині лежать творчі доробки автора. Здогадки підтверджує та доповнює текстовий коментар до портрету: «Пишіте, друзі, / День $і$ ніч, / $і$ набивайте руку, / Але не кваптесь / твори ті / нести до друку». Звідси випливає, що Дмитра Рудика оточуючі сприймали як надзвичайно вимогливого та прискіпливого і до себе, і до людей, причетних до мистецького життя, а Струхманчук і Шворка увиразнили ці позитивні риси.

Активними членами спілки, яка об'єднувала понад 50 літераторів і художників, уродженців західноукраїнських земель «Західна Україна», були В. Атаманюк, М. Гаско, В. Гжицький, Л. Дмитерко, Д. Загул, М. Ірчан, В. Касіян, М. Козоріс, Ф. Малицький, Я. Струхманчук, І. Ткачук, М. Марфієвич, А. Турчинська та ін. Подитячому добродушним та ситим зображено одного із них - Миколу Марфієвича. Текст: «I нині він тота сама дитина, / Що тридиять літ тому зродила Буковина. / 3 азартом марить про нещасний край, / Про хатку під ліском, про бриндзю $і$ малай» слугує підтвердженням такої думки, підкресливши спокійну вдачу Миколи та його любов до національних страв: бринзи та малая (паляниці з кукурудзяної муки). 
Жанр карикатури передбачає гіперболізм та загострене змалювання конкретної події чи людини, неочікуване зіставлення та перенесення образів із однієї сфери діяльності на іншу, що створює ефект комізму. Зауважимо, що карикатура забезпечує не лише ілюстрацію певної теми з якогось оригінального ракурсу, а й додає ій нових несподіваних інтерпретацій, змушує сприймати реалії буття крізь сміх і сльози водночас, є своєрідним актом психотерапії. Яків Струхманчук замість розлогих статей декількома порухами олівця зумів висловити ставлення до людей, яких зображував, власну точку зору на певну історичну епоху, виявив себе як людина $з$ тонким почуттям гумору, ерудит, професіонал. Знання людської психології та анатомії, дружба з портретованими, тонке розуміння вчинків близьких дозволило Якову розкрити їхню глибинну сутність, можливо, до кінця незрозумілу ні Кічурі, ні Атаманюку, ні Загулу, ні Рудику, ні будь-кому іншому. Виходячи з проаналізованого, можемо стверджувати, що ілюстрації Струхманчука створювали комунікативний зв'язок між побаченим і прочитаним. Митець був у вирі сучасності, тому такі актуальні проблеми, як взаємозв'язок між різними видами мистецтва, образність не оминули його уваги. Надалі цікаво було би простежити тісний взаємозв'язок драматургії Леся Курбаса та малярської спадщини Якова Струхманчука, оскільки це питання і до сьогодні залишається відкритим.

\section{БІБЛІОГРАФІЯ}

ЛЗТПЛ 2001 - Лексикон загального та порівняльного літературознавства ; за ред.

А. Волкова та ін. - Чернівці : Золоті литаври, 2001. - 636 с.

Лотман 2002 - Лотман Ю. Статьи по семиотике культуры и искусства / Ю. Лотман. - СПб. : Академический проект, 2002. - 544 с. (Серия «Мир искусств»). Погребенник 1997 - Погребенник Ф. На переломі // Художник Яків Струхманчук жертва сталінського терору [Публіцистика] ; за упоряд. та ред. О. Мусієнка. К. : Дніпро, 1997. - С. 59-80.

Сидор 1997 - Сидор О. Мистецтво Якова Струхманчука // Художник Яків Струхманчук - жертва сталінського терору [Публіцистика] / За упоряд. та ред.

О. Мусієнка. - К. : Дніпро, 1997. - С. 81-130.

Франко 1981 - Франко І. Із секретів поетичної творчості // Зібрання тв. : у 50 т. / Іван Франко. - К. : Наук. думка, 1976-1986. - Т. 31. - 1981. - С. 45-119.

Стаття надійшла 5 вересня 2013 р. 